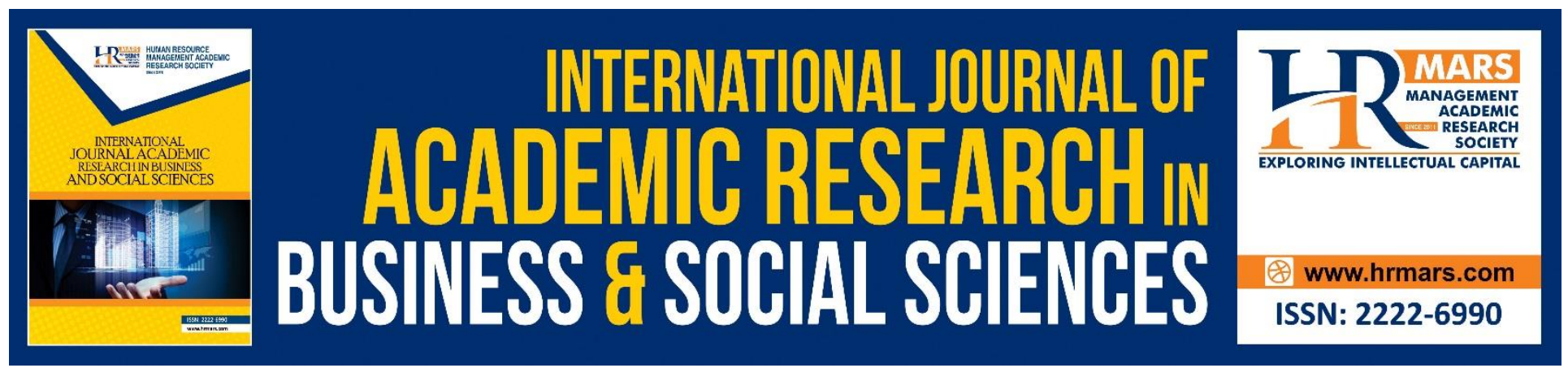

\title{
Contributions by Rogayah Sulong in Teaching and Learning the Al-Quran
}

Najmiah Omar, Zulkifli@Md Yaakub Mohd. Yusoff, Mohamed Fathy Mohamed Abdelgelil, Nor Hafizi Yusof, Mohamad Zaidin Mohamad, Fatima A. Alkohlani

To Link this Article: http://dx.doi.org/10.6007/IJARBSS/v8-i11/4994

DOI: $10.6007 /$ IJARBSS/v8-i11/4994

Received: 06 Nov 2018, Revised: 09 Dec 2018, Accepted: 15 Dec 2018

Published Online: 16 Dec 2018

In-Text Citation: (Omar et al., 2018)

To Cite this Article: Omar, N., Yusoff, Z. Y. M., Abdelgelil, M. F. M., Yusof, N. H., Mohamad, M. Z., \& Alkohlani, F. A. (2018). Contributions by Rogayah Sulong in Teaching and Learning the Al-Quran. International Journal of Academic Research in Business and Social Sciences, 8(11), 98-106.

Copyright: (C) 2018 The Author(s)

Published by Human Resource Management Academic Research Society (www.hrmars.com)

This article is published under the Creative Commons Attribution (CC BY 4.0) license. Anyone may reproduce, distribute, translate and create derivative works of this article (for both commercial and non-commercial purposes), subject to full attribution to the original publication and authors. The full terms of this license may be seen

at: http://creativecommons.org/licences/by/4.0/legalcode

Vol. 8, No. 11, 2018, Pg. 98 - 106

http://hrmars.com/index.php/pages/detail/IJARBSS

JOURNAL HOMEPAGE

Full Terms \& Conditions of access and use can be found at http://hrmars.com/index.php/pages/detail/publication-ethics 


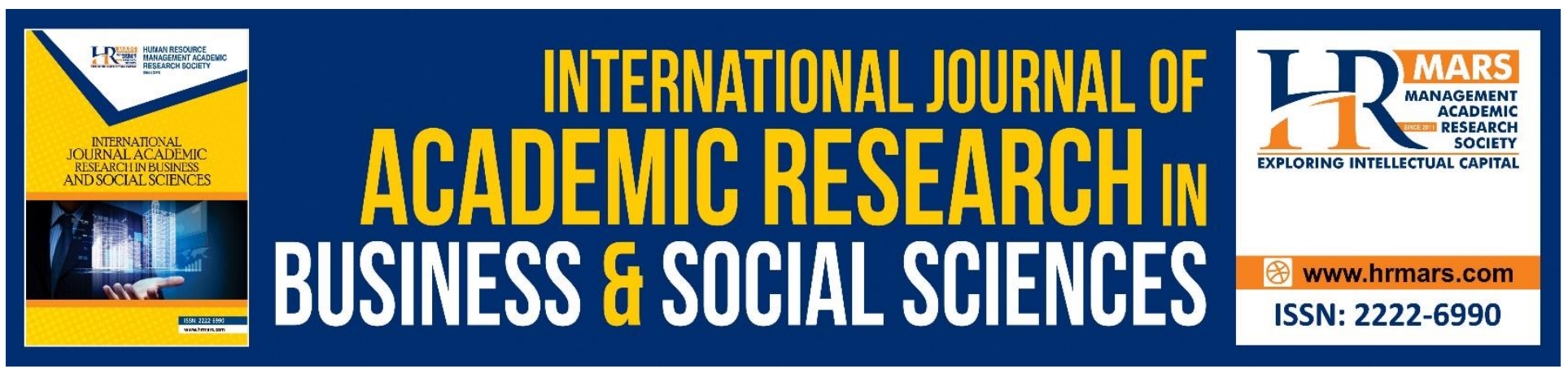

\title{
Contributions by Rogayah Sulong in Teaching and Learning the Al-Quran
}

\author{
${ }^{1}$ Najmiah Omar, ${ }^{2} Z$ ulkifli@Md Yaakub Mohd. Yusoff, ${ }^{1}$ Mohamed \\ Fathy Mohamed Abdelgelil, ${ }^{1}$ Nor Hafizi Yusof, ${ }^{1}$ Mohamad Zaidin \\ Mohamad, ${ }^{3}$ Fatima A. Alkohlani \\ ${ }^{1}$ University of Sultan Zainal Abidin (UniSZA, Malaysia \\ ${ }^{2}$ University of Malaya, Malaysia \\ King Abdulaziz University, Jeddah \\ Corresponding Author: mzaidin@unisza.edu.my
}

\section{Abstract}

This article describes the contributions of Rogayah Sulong in the field of the al-Quran and tarannum. Rogayah Sulong is a qariah who possesses expertise in the field of the Qur'an and tarannum. This article intended to describe and elaborate the contributions made by Rogayah Sulong in upholding the al-Qur'an while highlighting her contributions in the aspects of the Qur'an to oneself, the religious community and the nation. This study found that Rogayah Sulong deserves appreciation due to her persevering contributions in appreciating the kalamullah and love for the Quran.

Keywords: Contributions, al-Quran.

\section{INTRODUCTION}

Rogayah Sulong was a well-known international figure due to the Tilawah al-Qur'an competition organised by the Department for Islamic Development Malaysia. She first became known after becoming the champion several times at the national and international levels from 1961 to 1979. Her expertise was proven based on the number of times she had won competitions, which was nine times at the state level, seven times at the national level and four times at the international level. She was also the first woman from Terengganu to become the champion at the national and international levels. At the state level, she was the champion for the greatest number of times.

Throughout a period of 53 years between 1960 to 2013, more than half of the female champions at the Terengganu state level were related to her, either personally, as her student or a student to her student. This leads to the respect and admiration of the society shown towards her.

\footnotetext{
${ }^{1}$ Najmiah binti Omar is a PhD candidate at the Department of al-Quran and al-Hadith, Academy of Islamic Studies, Universiti Malaya, Email: najmiah@unisza.edu.my
} 
Hence, it is not surprising that the Terengganu people think highly of her as well as her students (Muhammad Zamri Nik, 8 May 2013). This indirectly explains the recognition given by the judges in the Tilawah al-Quran competition to her skills in reciting the al-Quran.

In addition, she has produced many students, not only in Terengganu but also in other states such as Sabah and Sarawak. This could be because she had travelled to these places, including Pahang, Johor and Sarawak, to teach the al-Quran and tarannum. Besides that, when she was in Terengganu, the states of Sabah and Sarawak had sent and sponsored several students to learn tarannum, specifically in her home. The teacher-student relationship had further spread the knowledge of tarannum to all over Malaysia. What is more interesting is that her husband, Megat Osman bin Megat Chik, was also involved in teaching tarannum.

In Terengganu, most of the champion qari and qariah at the Terengganu state level were students of Rogayah Sulong. This strongly suggests that Rogayah Sulong and her students had greatly dominated competitions at the state level. This did not include students who got second or third place at the Tilawah al-Quran. Most of the qari and qariah in Terengganu were related or were all taught by the same teacher. They learned tarannum from either of the same three sources, namely Haji Mat Lintar, Rogayah Sulong or Ahmad Som Pergau. In addition, some had familial relations and were related to each other.

\section{RECOGNITION}

Rogayah Sulong was involved in a career as an al-Qur'an and Tarannum teacher since 1961 until now under the auspices of the Terengganu state government (Wan Mohamad Sheikh Abdul Aziz, 10 June 2007). The name 'Rogayah Sulong' is also listed in the book Biography of Malaysian Women Figures (2004), which was published by the Islamic Women's Action Organization (PERTIWI), in appreciation of her contributions in glorifying the name of the country at the international level. She was also bestowed six awards and medals, as follows:

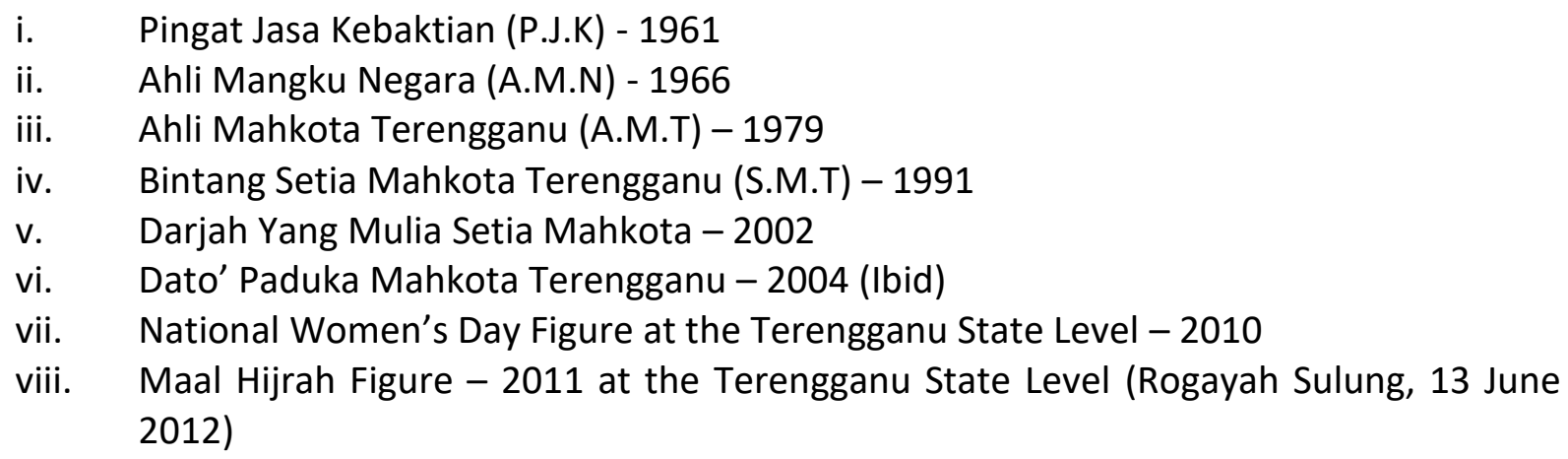

Besides the recognition at the national level, she was also recognized internationally. In 1966, she, together with some of her peers, such as Haji Ismail Hashim (Kedah) and Hajjah Faridah Mat Saman (Kelantan), were given the honour to listen to recitals of the al-Qur'an in Afghanistan, Iran, Egypt, Sudan, Somalia and Turkey. 
INTERNATIONAL JOURNAL OF ACADEMIC RESEARCH IN BUSINESS AND SOCIAL SCIENCES

Vol. 8, No. 11, Nov, 2018, E-ISSN: 2222-6990 @ 2018 HRMARS

\section{CONTRIBUTIONS}

The awards received by Rogayah Sulong is evidence of her contributions and services to society, especially in the field of teaching the al-Quran and tarannum. Among the contributions of Rogayah Sulong are:

\section{a. The Woman Who Pioneered the Field of Tarannum al-Quran}

Rogayah Sulong was one of the women who pioneered the field of tarannum al-Quran together with her peers. Rogayah Sulong was the first qariah to be involved in the world of tarannum during the 60 s era. Among the famous names in Terengganu at that time were Rokiah Daud, Wook Hasan, Safiah Muhammad and Nik Maliah Ismail. Rogayah Sulong was also the first woman in Terengganu who succeeded in becoming the champion during the Tilawah al-Quran competition organised by JAKIM at the national and international levels.

\section{b. Producing Future Students in Tarannum al-Quran}

Rogayah Sulong had also produced many future generation students in the field of tarannum alQuran. Among her contributions was that she trained future qari and qariah at the district and state levels. She also taught al-Quran dan tarannum in Pahang from 1958 to 1960 as well as in Johor for 4 years from 1961 to 1964. In 1988, she was sent to train the qari and qariah who were sent by the Sabah and Sarawak governments.

Thus, she was not only an attraction for local students but qariah from neighbouring countries such as Thailand and Singapore had also visited her to learn to become a qariah. She was a Guest Qariah at state level functions such as the Maulud Nabi celebrations. In short, she was a trainer of qari and qariah all over Malaysia as well as neighbouring countries including Brunei, Singapore, Thailand and Indonesia. (Islamic Religion and Malay Customs Council of Terengganu).

\section{c. To Teach Society to Appreciate The al-Quran}

Rogayah Sulong had taught the community to appreciate and love the al-Quran as well as to recite it well. She used to spend her days teaching the al-Quran and tarannum in mosques around Kuala Terengganu, Marang and Hulu Terengganu. Nowadays, in her old age, she restricts her teaching activities to mosques around Terengganu, such as mosques in Kuala-Berang, Padang Midin, Pengadang Baru as well as Surau Kg Tepoh. Besides that, she has converted her home into a place for teaching al-Quran including those who come on their own, either on a long-term or short-term basis.

Her sincere intentions in teaching, discipline, holding high esteem and patients were among the recipes of her success as financial income was not her motive. From a very young age and until this study began in 2012, she was still active in teaching tajwid, tarannum and qiraat Warsh. During the period of this study, the researcher had interviewed her and followed her tajwid class that involved the village community in Masjid Padang Midin, KualaTerengganu every Wednesday morning. Rogayah Sulong was strict when teaching tajwid and strongly emphasised on makhraj and the tenets of tajwid. Although she is strict, she is actually a friendly and motherly figure.

\section{d. Introducing Tarannum to Society}

Rogayah Sulong had also introduced tarannum to the society. She was one of the figures who was committed in delivering Quranic teachings and tarannum to society. This was evident in her willingness to teach the al-Quran no matter what time or day although at a ripe old age. The sincerity and love for the al-Quran was deep-founded. 
Rogayah Sulong invited her students who were learning tarannum to listen to tarannum alQuran recitals in mosques around Terengganu before starting religious sermons and collecting donations to help the Darul Falah Orphanage Hostel in Bukit Payong, Marang, Terengganu. Among those involved in helping her were Hajjah Maznah Awang and Dato' Haji Salleh Awang or also known as Misbaha.

\section{e. $\quad$ Producing Skilled Teachers in the al-Quran}

Rogayah Sulong produced skilled teachers in the al-Quran under the Terengganu Islamic Foundation. She has approximately 20 to 30 students per day for each location of study such as the mosque, surau or her own home. One special privilege enjoyed by those learning with Rogayah Sulong was that they received two certificates after memorising (khatam) the al-Quran, namely one from the Terengganu Islamic Foundation and a special certificate from Rogayah Sulong, which is a certificate in al-Quran studies (narration). However, students who had completed reciting the al-Quran with her but were not proficient enough did not receive their certificate of narration. This means that the certificate was meant for selected students only. She held the al-Quran memorising event every two years. Rogayah Sulong held the al-Quran memorising event in 2014. About 30 students had successfully memorised (khatam) the al-Quran with her and five students had successfully memorised the alQuran by reciting the qiraat warsh.

Rogayah Sulong taught the al-Quran as a form of a life-long learning experience. Learning the al-Quran does not stop by memorising (khatam) the al-Quran once. Moreover, there are many of her students who have memorised (khatam) the al-Quran more than once throughout their lives. Based on observations, the relationship between her and her students is very close. They often bring gifts from their farm every fruit season, attend functions and some who came from afar even spend the night at her home (personal observation). There are students who visit her and listen to recitals according to tarannum. Besides that, every time the Tiilawah al-Quran season at the district, state or national levels come around, her home is visited day and night by qari and qariah who train their recitals according to tarannum.

\section{f. $\quad$ Internationalising the Malay Race In al-Quran Recitals}

Rogayah Sulong proved to the world that the Malays are capable of reading the al-Quran well. She then proved that the miracles of the al-Quran could be recited well by non-Arab Muslims. The name Rogayah Sulong is not only famous in Malaysia, but is on the lips of Muslims all over the world. She is also well-known among international judges and her fellow compatriots. She was generous in dissipating knowledge to qari and qariah from overseas, especially countries like Indonesia, Brunei, Thailand and Singapore. The strains she delivered were just like strains by an Arabic qariah. She emphasised recitals that were natural, horizontal, with an orderly intonation as well as skilled in creating the burdah according to the place and situation.

\section{g. Becoming the Qari of the Terengganu Palace}

Rogayah Sulong was appointed as the qari of the Terengganu Palace. Each time Ramadan arrives, she would be invited to the Terengganu Royal Palace to recite the holy verses of the al-Quran according to tarannum during the time of Sultan Ismail Nasiruddin Shah. She would recite the holy verses of the al-Quran every night after the tarawih prayers (Rogayah Sulong, 5 June 2017) 
INTERNATIONAL JOURNAL OF ACADEMIC RESEARCH IN BUSINESS AND SOCIAL SCIENCES

Vol. 8, No. 11, Nov, 2018, E-ISSN: 2222-6990 @ 2018 HRMARS

h. Involved in Social Activities

Rogayah Sulong was also involved in social activities. She was the UMNO Women Chief for Kampung Pengkalan Setar in Kuala Terengganu from 1961 to 1965. She was once appointed as a Committee Member to the Darul Falah Orphanage in Bukit Payong, Kuala Terengganu. She had made financial contributions to the tune of RM60,000 to Darul Falah in Bukit Payong, Marang, Terengganu (Ibid) as well as appointed as a committee member of the Bukit Sawa Primary School PIBG in Marang, Terengganu from 1993 to 1995 as well as the Marang District Women's Association from 1991 to 1993 (Rogayah Sulong, 5 June 2017).

\section{Rogayah Sulong and Forming the Darul Falah Orphanage Hostel}

Rogayah Sulong was one of many who was actively involved in forming the Darul Falah Orphanage Hostel in Bukit Payong and became a committee member of Darul Falah. She was active in community activities. During the early part of the orphanage hostel's formation, it was headed by Dato' Haji Mohd Salleh Awang (Dato' Setia Jasa) or also known by his pen-name, MISBAHA, 'Founder of Darul Falah', who at that time was the Inspector of Religious Affairs, Terengganu with his main advisor being the Mufti of Terengganu Sahibul Samahah Syed Yusof al-Zawawi and assisted by committee members of PERKASA, which is short for Terengganu Islamic Welfare Organization (Muhd Zulkarnain Mukhtar, 25 January 2015).

PERKASA comprises visiting religious teachers and was founded on 15 Ramadhan 1365 / 12 August 1946 by the late Tuanku Sultan Zainal Abidin Al-Haj. Today, PERKASA is under the patronage of DYMM Sultan Mizan Zainal Abidin Ibni Al-Marhum Sultan Mahmud Al-Muktafi Billah Shah. Dato' Haji Wan Abdul Rahman Long, the Grant Kadi of Terengganu, who founded it was assisted by several officers from the Terengganu Department of Religious Affairs at that time. His main aim and intention were to widen efforts towards spreading dakwah Islamiyyah. open up the mind to strengthen it and initiate Islamic development among the people of Terengganu, as well as enhance their level of education and help those who are poor and dissolute.

PERKASA's membership is open to Muslims born in Terengganu Darul Iman. The number of registered members until 2015 was 1,825. Among the activities implemented by PERKASA are activities related to welfare, preaching (dakwah) and cooperation between authorities (Muhd Zulkarnain Mukhtar, 25 January 2015).

From the aspect of welfare and in accordance with the formation of PERKASA, this organization has frequently taken part in collecting donations from the public by visiting all the states, mosques and surau. Through these donations, PERKASA has played a role in helping those who need help such as building hostels for orphanages. Besides that, PERKASA also provides financial help for the poor, students and those who have recently embraced Islam (muallaf) as well as rural Islamic communities in Terengganu, Singapore, Jawa and Sumatera.

From the preaching (dakwah) aspect, among the activities were religious talks in mosques, surau and Usrah, especially for communities living in the interior. In addition, al-Quran classes in villages and Fardhu Ain classes carried out voluntarily by members who are religious teachers or visiting religious teachers. Besides that, PERKASA also carries out preaching (dakwah) among the 
INTERNATIONAL JOURNAL OF ACADEMIC RESEARCH IN BUSINESS AND SOCIAL SCIENCES Vol. 8, No. 11, Nov, 2018, E-ISSN: 2222-6990 @ 2018 HRMARS

Orang Asli living in the interior as well as campaigns among the public so that they can learn and understand Islam as well as practice it according to the demands of Allah s.w.t.

From the cooperation aspect, PERKASA always endeavours to carry the government's vision to form a society that is based on cooperation, unity as well as helping one another through books, brochures etc. In addition, PERKASA organises trips to centres of higher education and historical places for its members in order to open up their minds to the contemporary world.

In the beginning, Darul Falah was a mere hut used for teaching religion founded by Dato' $\mathrm{Hj}$. Wan Abdul Rahman Long or also known as Y.B Dato' Purba Di Raja, SPMT, KMN., PJK. Dato' Hj. Wan Abdul Rahman started service in the religious hut on 12 August 1946 until 3 June 1947 as the President of PERKASA (Muhd Zulkarnain Mukhtar, 25 January 2015). After him the task was taken over by Dato' Wan Abdullah Dato' Kamal Wangsa, or also known as Dato' Biji Sura, who served from 4 June 1947 to 20 June 1948. Then, the religious hut was taken over by Dato' Haji Kamaruddin Idris, or also known as Y.Bhg. Dato' Seri Setia Raja, who served from 21 June 1948 to 31 August 1957. Then, Haji Muhammad Salim Ahmad became the President of PERKASA beginning from 1 January 1958 to 31 August 1967. The position was then taken over by Hj. Musa and then by Dato' Hj. Mohd Salleh $\mathrm{Hj}$. Awang, or also known as Y. Bhg. Dato' Setia Jasa, beginning from 6 August 1971 to 31 August 1992. After Haji Mohd Salleh, Dato' Haji Omar Pilus held the position of President of PERKASA from 23 October 1993 to 15 April 2000, which was then taken over by Tuan Haji Yusof @Kabi Musa on 16 April 2000.

Darul Falah's orphanage hostel was formed on 30 July 1962. It was formed in order to cater for orphans who were poor and lacking proper care, without considering their level of academic achievement. These orphans were fully supported until they were able to be independent.

The orphans' hostel is under the auspices of PERKASA. Two individuals, namely a committee member in charge of the orphan's hostel and Rogayah Sulong, had made efforts to collect donations through the tarannum-based Tilawah al-Quran competition recited by her students. It began with a single building erected through the combined efforts of people living there (gotong-royong), while the cost was borne by donations amounting to RM60,000. The building was on a piece of land measuring 3,587 acres, which was donated by Tuan Haji Taib bin Ibrahim and situated in Kampung Padang Pak Su Man in Bukit Payung, Marang, Terengganu. In the beginning, the hostel housed 21 male orphans from all over Terengganu. It was officiated by Almarhum DYMM Sultan Ismail Nasiruddin Shah Ibni Almarhum Sultan Zainal Abidin, the Sultan of Terengganu Darul Iman.

Besides the DYMM Tuanku himself, who showed concern about Darul Falah, the Islamic Religious Office Terengganu, State Welfare Office, State Education Office and the public always extended their assistance to make Darul Falah an outstanding establishment until today (ibid). During the period from the formation of Darul Falah until today, 452 orphans have passed through its doors, comprising primary, secondary and university students with costs reaching approximately RM300,000 per year.

Each occupant received formal education in school. Their spare time was filled with various activities that prepared these children to become useful human beings. Among the activities were Fardhu Ain and al-Quran classes, caring for the orphanage, computer classes, sports and career club, tuition classes and personality development activities. The Darul Falah hostel always followed the trend of modern development in order to fulfil the organization's objective. 
INTERNATIONAL JOURNAL OF ACADEMIC RESEARCH IN BUSINESS AND SOCIAL SCIENCES

Vol. 8, No. 11, Nov, 2018, E-ISSN: 2222-6990 @ 2018 HRMARS

\section{Facilitator to the Qari and Qariah}

Rogayah Sulong was appointed as a trainer and facilitator to the qari and qariah who took part in the Tilawah al-Quran competition. She was also frequently appointed as a coach or facilitator during the Tahsin al-Quran Course in the 1980s and 90s. This course was held in three levels only for selected qari, specifically for qari who participated in the Tilawah al-Quran competition at the state, national and international levels. Usually, the Tahsin al-Quran course is held for a period of two to three days to a week.

She taught the reciting of qiraat Warsh to the community. Besides teaching the al-Quran qiraat Hafs, she also taught the recital of talaqqi according to the Warsh. The recital according to Warsh was only for selected students. One of the criteria for selecting these students was that they had to possess skills in reciting Hafs correctly according to the etiquette of reciting. Hence, students learning the Warsh under Rogayah Sulong were limited. She had studied Warsh in narration form and her teacher was Muhammad Imam Abu al-Ma'ati, a lecturer with the al-Quran Institute of Terengganu.

Rogayah Sulong and her peers had succeeded in glamorising the nation at the international scene and she has been frequently invited as a guest qariah either locally or internationally. Based on observations, her recorded recitals have also been sold abroad, including the Middle East and Morocco. The Arabs themselves were amazed with her recital skills and quality.

Rogayah Sulong also taught the bilal various intonations of the azan. Other than teaching tarannum during the tilawah, she also taught the bilal from various mosques on how to call the azan according to tarannum. The intonations of the azan were similar to the intonation in recitals according to tarannum. Usually, calling of the azan is taught every Friday morning, together with the al-Quran and tarannum classes.

Her expertise was again in the limelight when one of her students succeeded in becoming the champion in the Tilawah al-Quran competition at the national and international levels. She has so many students, not only in Malaysia but also in Singapore and Thailand. Hence, behind the champion is surely Rogayah Sulong, who has her own style, strategy and method in nurturing and grooming future champions. Her teaching style is to firstly train students to be skilled in tajwid. Then, among these students who are skilled in tajwid, she selects those who possess a melodious and good voice to learn the tarannum.

\section{CONCLUSION}

Rogayah Sulong is a renowned figure in tarannum, who has the talent and potential for teaching tarannum al-Quran. She possesses a natural talent and a family who loves the al-Quran. She also endeavoures to rekindle the culture and atmosphere for teaching the al-Quran to her relatives, neighbours and community who are living near her. Besides her talented peers, other factors, such as teachers who are skilled, enthusiastic and strongly committed, are sources of her success in the field of tarannum al-Quran. She was chosen for this study because she frequently dominated the scene by becoming the champion in Tilawah al-Quran competitions among the qariah in Terengganu at the state, national and international levels.

Moreover, her students had also successfully dominated at the state and national levels. She has her own advantage in terms of her voice and the ability to intonate her voice during high notes, 
which many of the qariah of her time found difficult to match. Her voice was another factor that contributed to her success in the field of tarannum al-Quran. Her living conditions from a very young age had driven her successful career until today. She was raised in a family that loves the al-Quran. Her parents and relatives were amongst those active in teaching al-Quran to the community because studying the al-Quran was compulsory for daughters at that time, which has since become a practice and tradition among the community today.

Rogayah Sulong married a man who was an expert in the field of tarannum and he had identified her talent as well as always encouraged her to excel in the field of tarannum. Hence, her talent developed and her life headed for the better as she was always adorned by the virtues of the al-Quran. Her daily schedule was taken up by al-Quran classes at the surau, mosques or her home, both during the day and at night.

Rogayah Sulong is a qariah of high standards and quality. Her expertise has been passed-on only to students who are truly qualified and she safe-guards the quality of these students right from the beginning. The main criteria for her selection was the voice. Emphasis was given to the tajwid and ability to correctly pronounce the letters of the al-Quran as well as the fasahah and musical aspects. Therefore, Rogayah Sulong's students have succeeded in the field of tarannum and many have become champions during the Tilawah al-Quran competition, either at the district, state, national or international levels.

\section{ACKNOWLEDGEMENT}

Special thanks to Research Management, Innovation \& Commercialization Centre (RMIC) and University Sultan Zainal Abidin (UniSZA) for funding this research

\section{REFERENCES}

Muhammad Zamri Nik. 8 May 2013. Interview.

Rogayah Sulung. 5 June 2017. Interview.

Wan Mohamad Sheikh Abdul Aziz. 10 June 2007. Interview.

Muhd Zulkarnain Mukhtar. 25 January 2015. Interview. 